\title{
Efficacy of Rhizosphere Bacterial Antagonists and Plant Growth Promoting Rhizobacteria against Sclerotium rolfsii Affecting Tomato Plants
}

\author{
Bhanothu Shiva $^{1 *}$, P. Srinivas ${ }^{2}$ and Deepa Khulbe $^{3}$ \\ ${ }^{1}$ Department of Plant Pathology, Faculty of Agriculture, BCKV, Mohanpur-741252, India \\ ${ }^{2}$ Central Horticultural Experiment Station (ICAR-IIHR), Aiginia, \\ Bhubaneswar-751019, India \\ ${ }^{3}$ Regional Research and Technology Transfer Station, OUAT, Bhubaneswar-751003, India \\ *Corresponding author
}

\begin{abstract}
A B S T R A C T
Tomato is affected by a large number of diseases. Among these, collars rot disease of tomato cause by $S$. rolfsii is a threatening disease in eastern coastal regions of Odisha. Since, this disease is soil borne in nature, it is very difficult to control by chemical fungicides. The native rhizosphere soil of tomato was used for isolation and screening of bacterial antagonists for their efficacy and growth promotion potential. A total of 54 bacterial isolates were isolated from rhizosphere of tomato of which five isolates viz. Iso01, Iso-17, Iso-23, Iso-24 and Iso-32 were found effective for inhibition of the mycelial growth of $S$. rolfsii in dual culture. Highest inhibition of radial mycelial growth of pathogen in dual culture was induced by Iso-32 (75.6\%) and Iso-24 (71.1\%). In greenhouse experiment to manage collar rot in artificially inoculated tomato plants in portrays, the percent disease incidence (PDI) was minimum in treatment by Iso-32 (8.8\%) and Iso-24 (9.8\%), respectively. Similarly, percent disease reduction over control was highest with treatment with Iso-32 (85.1\%) followed by Iso-24 (83.4\%). Plant length, fresh and dry weight was also enhanced significantly due to the treatment of various isolates. The higher vigour index recorded with Iso-32 (1419) followed by Iso-24 (1387.3) as compared to vigour index (680) in non-treated control. It is concluded that native rhizobacterial strains can be successfully used for managing soil borne Sclerotium $s p$. affecting tomato crop while enhancing the growth of the treated plants.
\end{abstract}

\section{Keywords}

Tomato, PGPR, Biocontrol, Sclerotium rolfsii

Article Info

Accepted: 17 June 2019 Available Online: 10 July 2019

\section{Introduction}

Tomato (Solanum lycopersicum L.) is the important vegetable crop grown all over the world. Since, tomato plays an important role in human health; the quality of the nutritional components of this major vegetable crop is of

particular concern to producers and
consumers throughout the world. Due to its
extensive cultivation in diversified areas,
several biotic and abiotic factors have
emerged as a major constraint in its successful
cultivation. Among the biotic factors, diseases
i.e., collar rot (Sclerotium rolfsii), is

particular concern to producers and consumers throughout the world. Due to its extensive cultivation in diversified areas, several biotic and abiotic factors have cultivation. Among the biotic factors, diseases i.e., collar rot (Sclerotium rolfsii), is 
becoming sever disease of tomato in India. It caused 30 per cent of crop loss in Tomato (Thiribhuvanamala et al., 1999). Banyal et al., (2008) reported collar rot caused by Sclerotium rolfsii is one of the major threats in Himachal Pradesh, India, with an incidence of $10-45 \%$. The disease is distributed in tropical and sub-tropical regions of the world where high temperatures prevail. Sclerotium rolfsii, the causal agent of collar rot of many crops (Aycock, 1966) having a wider host range (Talukdar, 1974 and Bhattacharrya et al., 1977) attracted the attention of plant pathologist and professional researcher throughout the world. The pathogen is a soil inhabitant, very aggressive nature, attacks the collar portion of plant, which ultimately leads to its death. The infection leads to the drying of lower leaves and eventually the whole plant dries giving a typical symptom of wilting. Begum et al., (1985) explained that the collar rot of tomato may occur at any growth stage of the plant.

As agricultural production intensified over the past few decades, producers became more and more dependent on agro-chemicals as a relatively reliable method of crop protection. The use of chemical pesticides has caused soil pollution and harmful effects on human beings. One of the most acceptable and environmentally conscious approaches to solve these problems is the use of naturally occurring microbial inoculants. PGPR have gained worldwide importance and interest because of their agricultural benefits and are thus potential tools for sustainable agriculture for the future (Kloepper et al., 2007). The use of (PGPR) offers an alternative way to replace and /or supplement chemical fertilizers and pesticides. Soil bacteria living in the rhizosphere can enhance plant growth by several mechanisms like antagonism against plant pathogens, solubilization of phosphates (De Freitas et al., 1997), production of phytohormones (Frankenberger and Arshad 1995; Arshad and Frankenberger 1998), siderophores production (Kloepper et al., 1980; Raaska et al., 1993), antibiotic production (Schinder et al., 1994). Utilization of these beneficial microorganisms can reduce the use of pesticides and fertilizers that are potential pollutants of the environment.

\section{Materials and Methods}

The study was carried out during 2017-18 in the Department of Plant Pathology, Odisha University of Agriculture and Technology (OUAT), Bhubaneswar, Odisha, India, which Agro-climatically falls under East \& South East Coastal Plain zone.

\section{Isolation of pathogen and native rhizobacteria}

Several diseased tomato plants were collected during the field surveys. The pathogen was isolated from diseased plant part in water agar and sub-cultured on Potato Dextrose Agar (PDA). The fungus, Sclerotium rolfsii, produced white, dense radiating mycelial growth in early stages of its growth on PDA and later produced matured spherical to ellipsoidal sclerotia. The pathogenicity of the isolate of $S$. rolfsii was proved under artificial condition on tomato seedlings. The inoculum of the pathogen was grown on milled maize grain seeds, added to the moistened coir pith @ $10 \mathrm{~g} \mathrm{~kg}^{-1}$ and mixed thoroughly. Suitable check was maintained without addition of inoculum to the coir pith. The seedling crates were watered at regular interval to maintain soil moisture. The seedlings were observed after 15 days for symptom development. Reisolation of the fungus (Sclerotium spp.) was done from infected seedlings and the cultures obtained were compared with initial cultures to confirm the identity and pathogenicity of pathogens.

Isolation of native rhizobacteria from collected soil samples was carried out by dilution plate technique as described by Islam 
(2009) on nutrient agar (NA). The Plates were incubated at $25^{\circ} \mathrm{C}+2$ for $2-4$ days in inverted position so that vapours condensed from the lid may not hamper the growth of the isolated bacteria. After incubation bacterial colonies were counted and representative colonies were selected, isolated, purified and maintained in NA slants for further use.

Screening and evaluation of selected antagonistic native rhizobacteria against $S$. rolfsii

In vitro screening of rhizobacterial isolates for their antagonist properties againstS. rolfsii

The antagonistic potential of the rhizobacterial native isolates against soil borne fungal pathogens was investigated by dual culture method (Dennis and Webster, 1971a, Buysens and Scheffer, 1992). The extent of antagonistic activity by rhizobacterial isolates against $S$. rolfsii pathogen was recorded on fifth day by measuring the radial growth of the pathogen in dual culture plates and in control plate. The per cent inhibition of radial growth of $S$. rolfsii over control was calculated (Vincent (1927).

Percentage inhibition $=\frac{(\text { Control-Test })}{\text { Control }} \times 100$

In-vivo screening of antagonistic rhizobacteria against $S$. rolfsii

To study the efficacy of rhizobacterial isolates selected through in-vitro screening, the surface sterilized tomato seeds (cv. ArkaRakshak, Pusa Ruby, Arka Samrat and ArkaMeghali) were planted in the protrays containing standard soil media inoculated with $S$. rolfsii. After one week and one day before transplanting the tomato seedlings, selected rhizobacterial isolates were incorporated in soil media at the rate of $5 \mathrm{ml}$ per well at $10^{9} \mathrm{cfu} / \mathrm{ml}$. Three weeks old seedlings were root dipped in bacterial suspension of selected antagonistic bacteria $\left(10^{9} \mathrm{cfu} / \mathrm{ml}\right)$ for $45 \mathrm{~min}$ and transplanted into pathogen-rhizobacteria mixture coir pith (Lemessa and Zeller, 2007). The seedlings were maintained in green house at $24-28^{\circ} \mathrm{C}$ temperature and $75-90 \%$ relative humidity. The seedlings were watered with sterile water when necessary.

\section{In-vivo evaluation of selected antagonistic rhizobacteria for biocontrol of $S$. rolfsii}

Five selected rhizobacterial isolates with higher inhibition under in vitro tests were further tested in green house on tomato plants to evaluate their ability to control soil borne diseases. Portrays containing standard soil mix and milled maize grains inoculated with $S$. rolfsii. After one week and one day before transplanting the seedlings, antagonists were incorporated in the coir pith at a rate of $5 \mathrm{ml}$ per well at $10^{9} \mathrm{cfu} / \mathrm{ml}$. Three weeks old tomato seedlings were root dipped in bacterial suspension of antagonistic bacteria $\left(10^{9} \mathrm{cfu} / \mathrm{ml}\right)$ for $45 \mathrm{~min}$ and transplanted into pathogen-antagonist mixture coir pith (Lemessa and Zeller, 2007). Treatments were replicated four times. Appropriate positive and negative controls were maintained. The disease incidence and biocontrol efficiency were calculated as follows:

Percent incidence $=$

Number of diseased plants $\quad$ x 100

Total number of plants observed

\section{Screening of rhizobacteria for plant growth response}

Selected rhizobacterial isolated were tested for plant growth response by seed treatment through rolled towel paper method, in vitro, and root dip method in pot culture under greenhouse condition. 
Effect of seed treatment with antagonistic rhizobacteria on plant growth response assessed by rolled paper towel method

One hundred seeds treated with respective selected isolates were randomly taken from each treatment with four replications and were placed uniformly between a pair of moist germination roll paper towels. The towels were rolled and the two ends were closed with rubber band. Then the rolled papers containing seeds were placed in an upright position for 7-10 days at room temperature under normal 12/12 light and darkness cycle. After incubation the shoot and root portions were blotted dry with fine tissue paper and fresh weight was taken. Length of shoot was measured from the base of the stem up to the growing point of the youngest leaf. Similarly, length of root was measured from the starting point of the root to the largest available lateral root tip. Germination percentage was calculated by the formula given below:

Germination $(\%)=$

Number of seeds germinated $\times 100$

Total number of seeds

The seedling vigour index was calculated by using the formula as described by Baki and Anderson (1972):

Seedling Vigor Index $=($ Root length + Shoot length) $x$ Seed germination $(\%)$.

In vivo effect of root dip treatment with antagonistic rhizobacteria on plant growth response

Greenhouse study was conducted for in vivo evaluation of antagonistic potential of selected rhizobacteria by root dip treatment in tomato. Seedling root dip treatment was done as per the method described by Srinivasan et al., (2009). Seedlings of tomato were grown in protrays. Two weeks old seedlings were taken out and roots were gently washed and dipped in the inoculum of respective rhizobacterial culture broth for $10 \mathrm{~min}$. The treated seedlings were then grown in pots under greenhouse condition. Plant growth promotion was assessed after two weeks in terms of growth parameters like root length, shoot length, fresh root weight, fresh shoot weigh, dry root weight and dry shoot weight.

\section{Statistical analysis}

The data obtained in the experiments was analysed using appropriate analysis programme -Statistical Methods for Agricultural Workers, ICAR, New Delhi (Panse and Sukhatme, 1989).

\section{Results and Discussion}

\section{Isolation and identification of soil borne pathogen}

The soilborne pathogen $S$. rolfsii was isolated from diseased samples of tomato plants collected from the OUAT fields, RRTTS farm, CHES farm and local farmer's fields during survey. The fungus produced white, dense radiating mycelial growth on PDA. In early stages, the mycelium was silky white which later became dull in appearance. Sclerotial initials were observed from $6^{\text {th }}$ day onwards. At the initial stage, the sclerotial bodies were white in colour later they turned buff brown colour to chocolate brown at maturity. On the basis of these characters the fungus was identified as $S$. rolfsii (Mordue, 1974; Farr et al., 1995). S. rolfsii produced typical symptoms of collar rot on tomato (cv. Arka Rakshak, Pusa Ruby, Arka Samrat and Arka Meghali). Profuse white mycelial growth was found on the soil surface after 24 hours of inoculation. White cottony growth at collar region and root zone was observed in 
wilted plants. Numerous round brown and mustard seed like sclerotia were seen on soil surface and root region of the infected plants at 9 days after inoculation.

\section{Screening of isolated rhizobacteria for} antagonistic potential

Preliminary in-vitro bioassay of isolated rhizobacterial isolates was carried out against Sclerotium sp. by the dual culture method. The intensity of the antagonism by various isolates against the pathogens was recorded as percent inhibition of mycelial growth by scoring in a scale from 0 (no inhibition) to $>75 \%$ as $(+++++)$ (data not presented). The efficiency of isolates $01,17,23,24$ and 32 was highest (55\% inhibition or more), while other strains were either inferior or inefficient in checking the mycelial growth of the pathogens.

\section{In vitro evaluation of selected rhizobacterial isolates against $S$. rolfsii}

In vitro evaluation of selected rhizobacterial isolates (isolate-01, isolate-17, isolate-23, isolate-24 and isolate-32), against Sclerotium spp. was carried out using dual culture method to test their efficiency to inhibit the mycelial growth of isolated fungal plant pathogen.

Antagonistic activity of selected rhizobacterias against $S$. rolfsii. by dual culture method

The data presented in the given Table 1, have been revealed that antagonistic effect of all the selected isolates against $S$. rolfsii showed significant reduction in mycelial growth. The per cent inhibition over control in collar rot disease ranged from 75.6 to 61.1 per cent. Maximum per cent inhibition over control was shown by isolate-32 (75.6 per cent) followed by isolate-24 (71.1).
In vivo evaluation of selected native antagonistic rhizobacteria for against collar rot disease

The effect of selected antagonists was investigated for their biocontrol potential against collar rot disease. All the isolates gave significant control of collar rot and wilt diseases when compared with inoculated control. Incidence of the diseases reduced to the level of $8.8 \%$ with isolate- 32 which gave $85.1 \%$ disease control over inoculated control. Effect of seed treatment with native rhizobacterial isolates on seed germination in artificially inoculated protrays under greenhouse conditions was also evaluated in below Table 2 .

The results (Fig. 1) showed that the percent germination of tomato seeds treated with five rhizobacterial isolates ranged between $86 \%$ and $94 \%$ as compared to $21 \%$ germination in control treatment plants inoculated with collar rot pathogen alone. Among individual isolates isolate-32 effected highest germination (94\%) followed by isolate-24 (92\%).

\section{Plant growth response}

Based on the screening for antagonistic potential revealed through dual culture technique and other characteristics, five isolates were selected and studied in detail plant growth response through in-vitro seed treatment by using rolled towel method and by root dip method under greenhouse condition.

In-vitro seed treatment with selected native bacterial isolates on seedling growth assessed by roll towel method

Effect of seed treatment with selected rhizobacterial isolates on germination, root length, shoots length, and vigour index were recorded and showed in below Table 3 . 
Table.1 Antagonistic activity of rhizobacterial isolates against S.rolfsiiin dual plate

\begin{tabular}{|c|c|c|c|}
\hline Treatment & $\begin{array}{c}\text { Radial growth } \\
(\mathbf{m m}) *\end{array}$ & $\begin{array}{c}\text { Per cent inhibition } \\
\text { over control* }\end{array}$ & $\begin{array}{c}\text { Inhibition zone } \\
(\mathbf{m m}) *\end{array}$ \\
\hline Iso-01 & 30.7 & 65.9 & 15.7 \\
\hline Iso-17 & 33.0 & 63.3 & 13.7 \\
\hline Iso-23 & 35.0 & 61.1 & 14.7 \\
\hline Iso-24 & 26.0 & 71.1 & 18.7 \\
\hline Iso-32 & 22.0 & 75.6 & 21.0 \\
\hline Control & 90.0 & 0.0 & 0.0 \\
\hline SE(m) \pm & 0.6 & 0.7 & 0.4 \\
\hline C.D. $\leq(\mathbf{0 . 0 5})$ & 1.8 & 2.1 & 1.1 \\
\hline
\end{tabular}

Table.2 Effect of seed treatment with native rhizobacterial isolates on in vivo incidence of collar rot under artificial inoculation of pathogen

\begin{tabular}{|c|c|c|}
\hline Treatment & Disease Incidence (\%) & Disease reduction over control $(\%)$ \\
\hline Iso-01 & 12.3 & 79.2 \\
\hline Iso-17 & 11.5 & 80.5 \\
\hline Iso-23 & 12.8 & 78.4 \\
\hline Iso-24 & 9.8 & 83.4 \\
\hline Iso-32 & 8.8 & 85.1 \\
\hline Control & 59.2 & 00.0 \\
\hline $\mathrm{SE}(\mathrm{m}) \pm$ & 1.7 & \\
\hline C.D. $(\leq \mathbf{0 . 0 5})$ & 4.9 & \\
\hline
\end{tabular}

Table.3 Effect of seed treatment with native rhizobacteria on seedling growth parameters

\begin{tabular}{|c|c|c|c|c|}
\hline Treatment & Germination \% & $\begin{array}{c}\text { Root length } \\
(\mathbf{c m})\end{array}$ & $\begin{array}{c}\text { Shoot length } \\
(\mathbf{c m})\end{array}$ & Vigour Index \\
\hline Iso-01 & 91.25 & 4.30 & 4.33 & 787.7 \\
\hline Iso-17 & 92.50 & 5.39 & 5.52 & 1011.1 \\
\hline Iso-23 & 88.75 & 7.66 & 7.98 & 1419.1 \\
\hline Iso-24 & 93.75 & 7.44 & 7.28 & 1387.3 \\
\hline Iso-32 & 96.25 & 6.72 & 6.62 & 1268.8 \\
\hline Control & 85.00 & 3.91 & 3.90 & 680.1 \\
\hline SE(m) \pm & 2.205 & 0.24 & 0.19 & 41.281 \\
\hline C.D. $(\leq \mathbf{0 . 0 5})$ & 6.602 & 0.72 & 0.56 & 123.6 \\
\hline
\end{tabular}


Table.4 Efficacy of potential antagonistic bacteria on enhancing seedling growth parameters of tomato crop under greenhouse condition

\begin{tabular}{|c|c|c|c|c|c|c|}
\hline \multirow[b]{2}{*}{ Treatment } & \multicolumn{3}{|c|}{ Root Parameters } & \multicolumn{3}{|c|}{ Shoot Parameters } \\
\hline & $\begin{array}{l}\text { Length } \\
(\mathrm{cm})\end{array}$ & $\begin{array}{l}\text { Fresh weight } \\
\text { (gm) }\end{array}$ & $\begin{array}{l}\text { Dry weight } \\
\text { (gm) }\end{array}$ & $\begin{array}{l}\text { Length } \\
(\mathrm{cm})\end{array}$ & $\begin{array}{l}\text { Fresh weight } \\
\text { (gm) }\end{array}$ & $\begin{array}{l}\text { Dry weight } \\
\text { (gm) }\end{array}$ \\
\hline Iso-01 & 14.65 & 0.79 & 0.41 & 14.80 & 1.28 & 0.57 \\
\hline Iso-17 & 15.25 & 0.92 & 0.53 & 15.40 & 1.41 & 0.81 \\
\hline Iso-23 & 14.00 & 0.79 & 0.40 & 14.30 & 1.23 & 0.46 \\
\hline Iso-24 & 15.40 & 0.94 & 0.48 & 15.58 & 1.43 & 0.86 \\
\hline Iso-32 & 15.33 & 0.96 & 0.50 & 15.58 & 1.43 & 0.98 \\
\hline Control & 9.48 & 0.64 & 0.30 & 9.98 & 0.56 & 0.31 \\
\hline $\mathrm{SE}(\mathrm{m}) \pm$ & 0.19 & 0.02 & 0.02 & 0.22 & 0.03 & 0.03 \\
\hline C.D. $(\leq 0.05)$ & 0.58 & 0.06 & 0.05 & 0.65 & 0.08 & 0.08 \\
\hline
\end{tabular}

Fig.1 Effect of seed treatment with native rhizobacterial isolates on germination (\%) under in vivo conditions

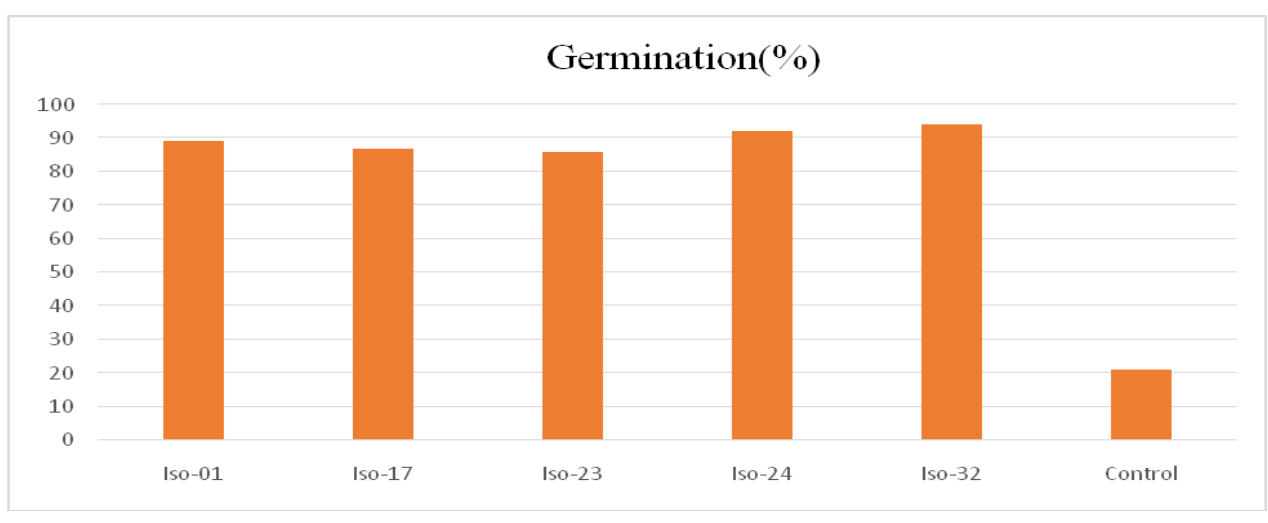

Plate.1 Pure culture of Sclerotium rolfsii

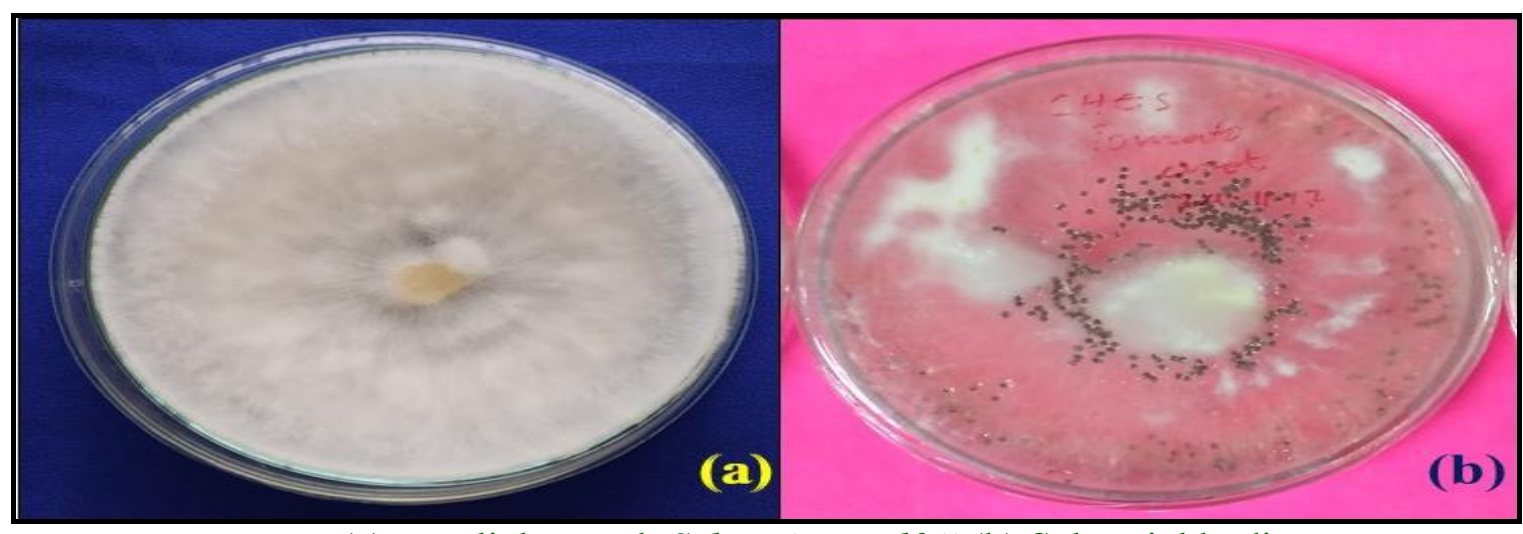

(a)mycelial growth Sclerotium rolfsii (b) Sclerotial bodies 
Plate.2 Pathogenicity test

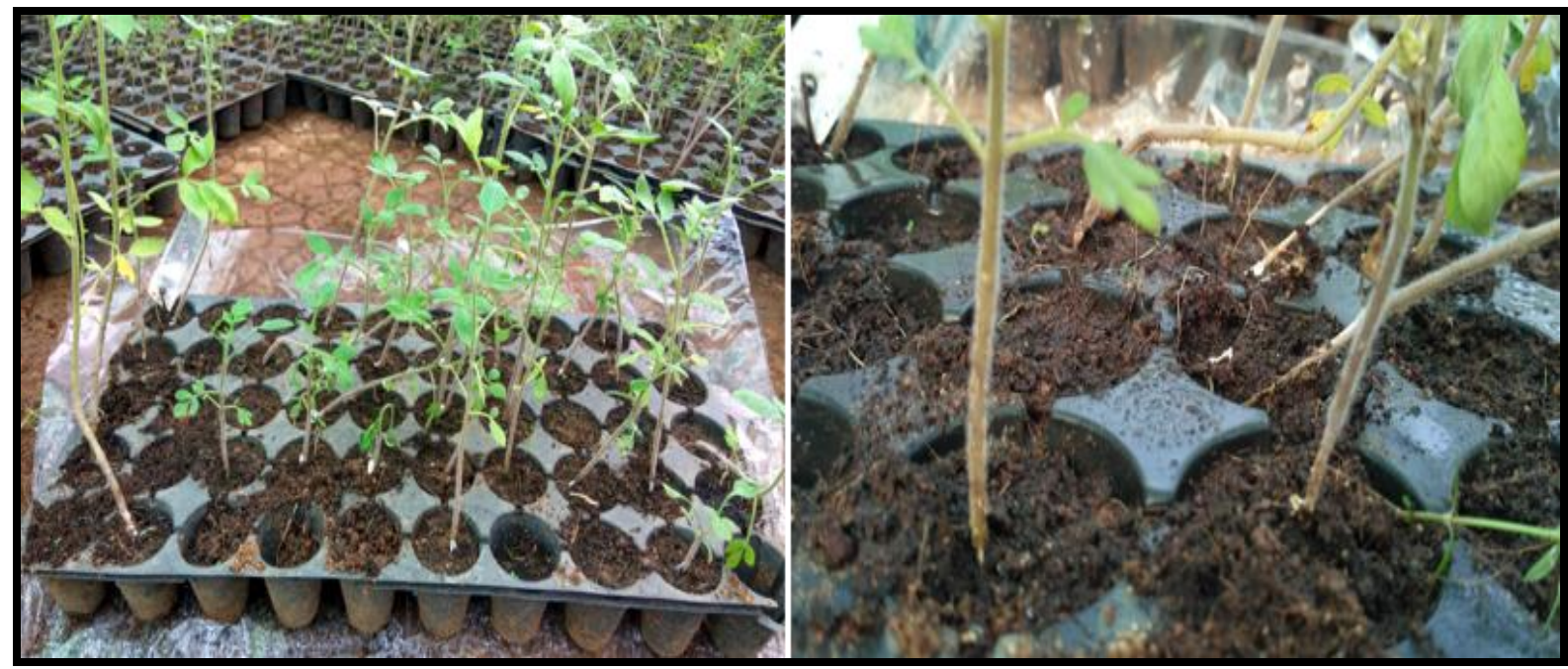

Typical symptom of collar rot (stem girdling) in tomato

Plate.3 Pure cultures of selected rhizobacterial isolates
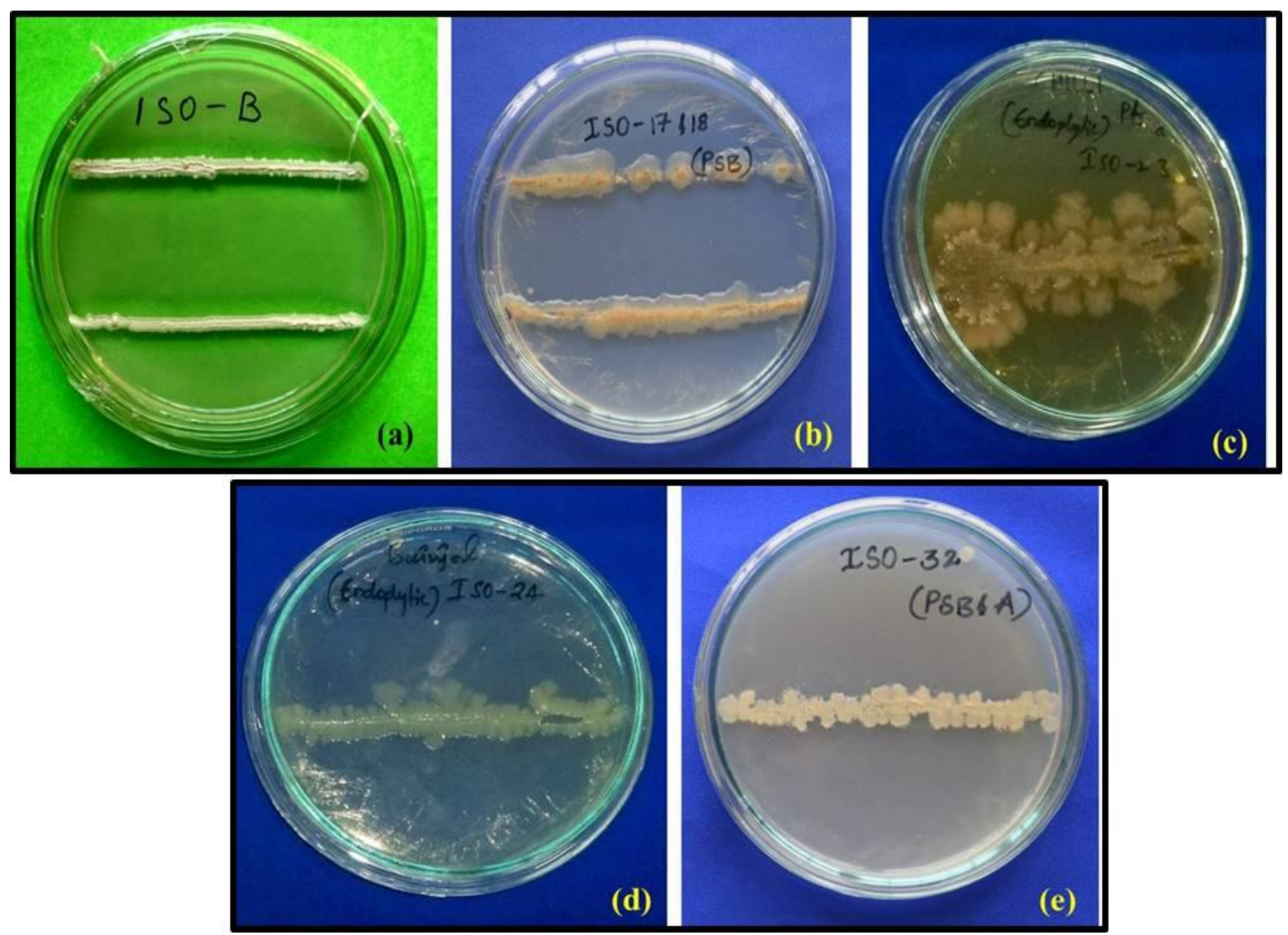
Plate.4 Dual culture of selected rhizobacterial isolates with Sclerotium rolfsii

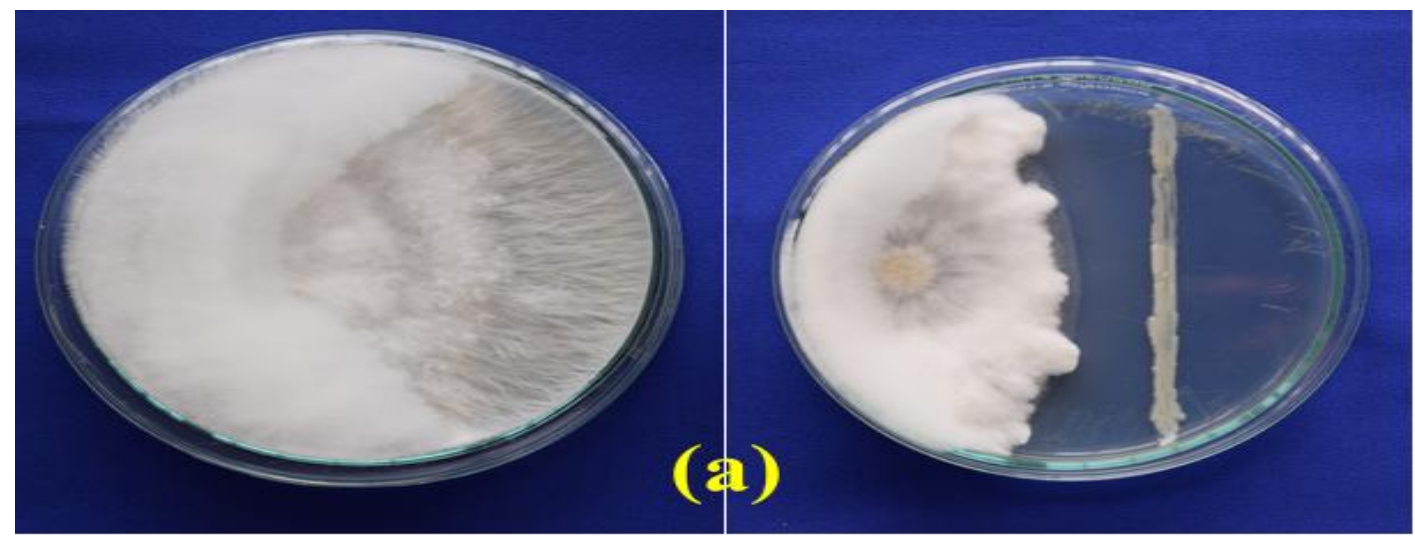

Plate.5 Mass multiplication of Sclerotium rolfsiiandbacterial isolates
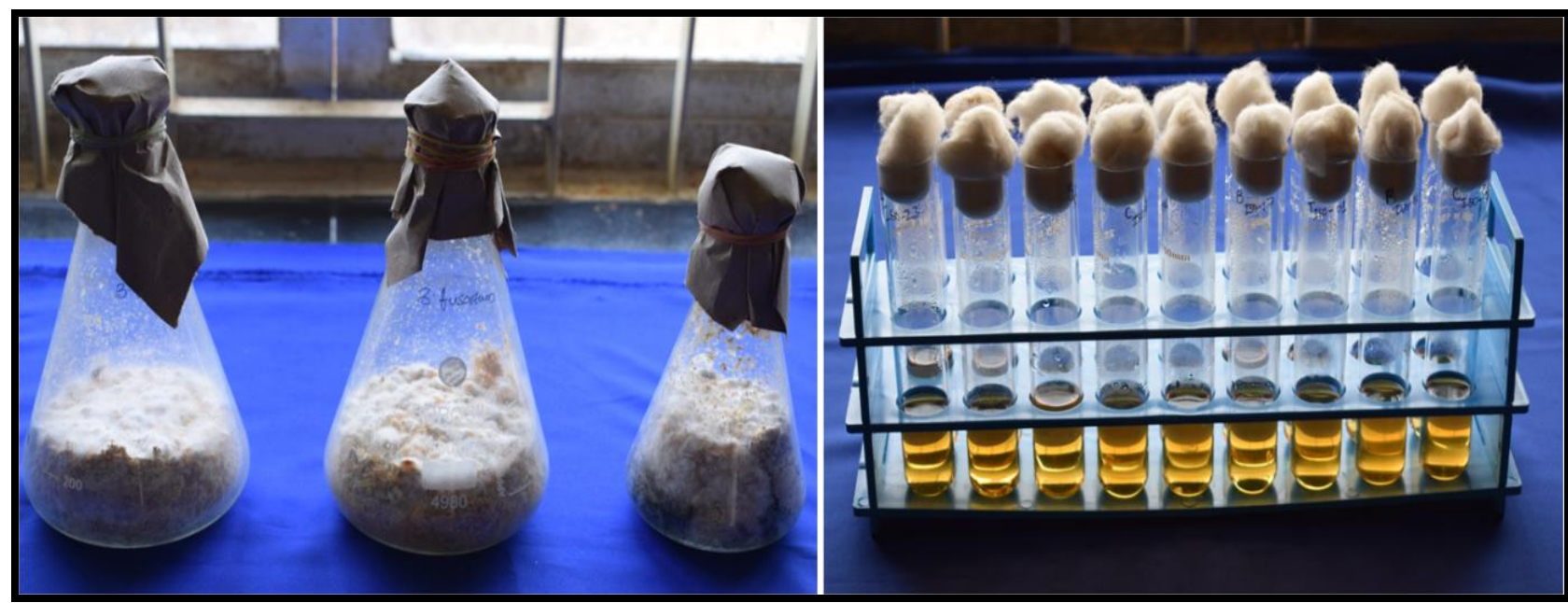

Plate.6 Effect of rhizobacteria on management of collar rot

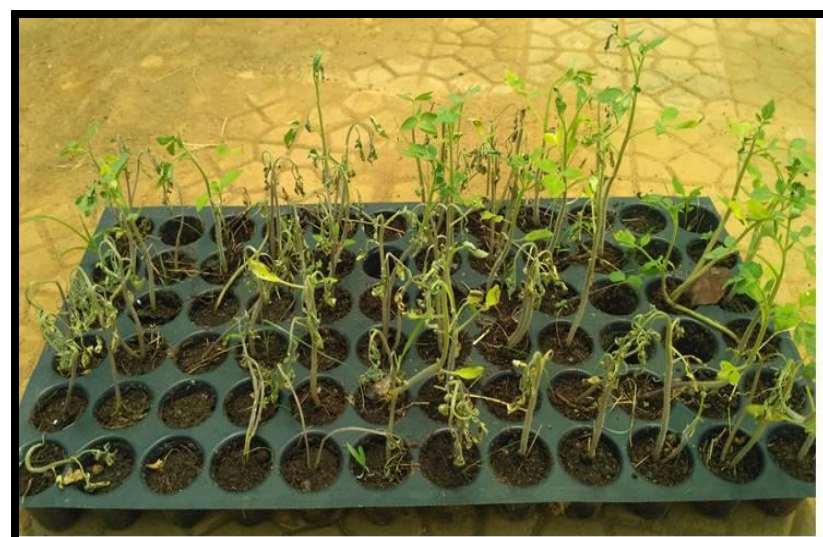

Pathogen inoculated control

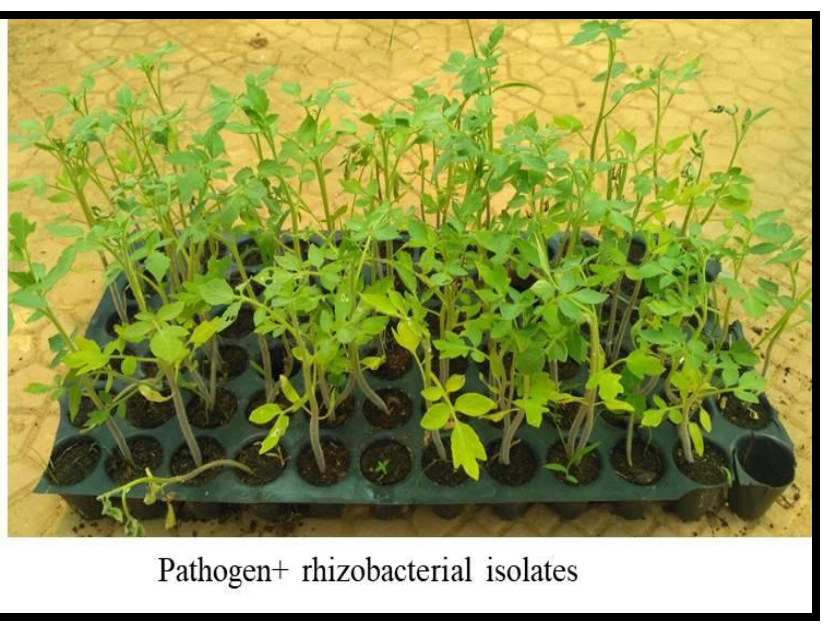


Plate.7 Effect of rhizobacterial seed treatment by roll paper towel method

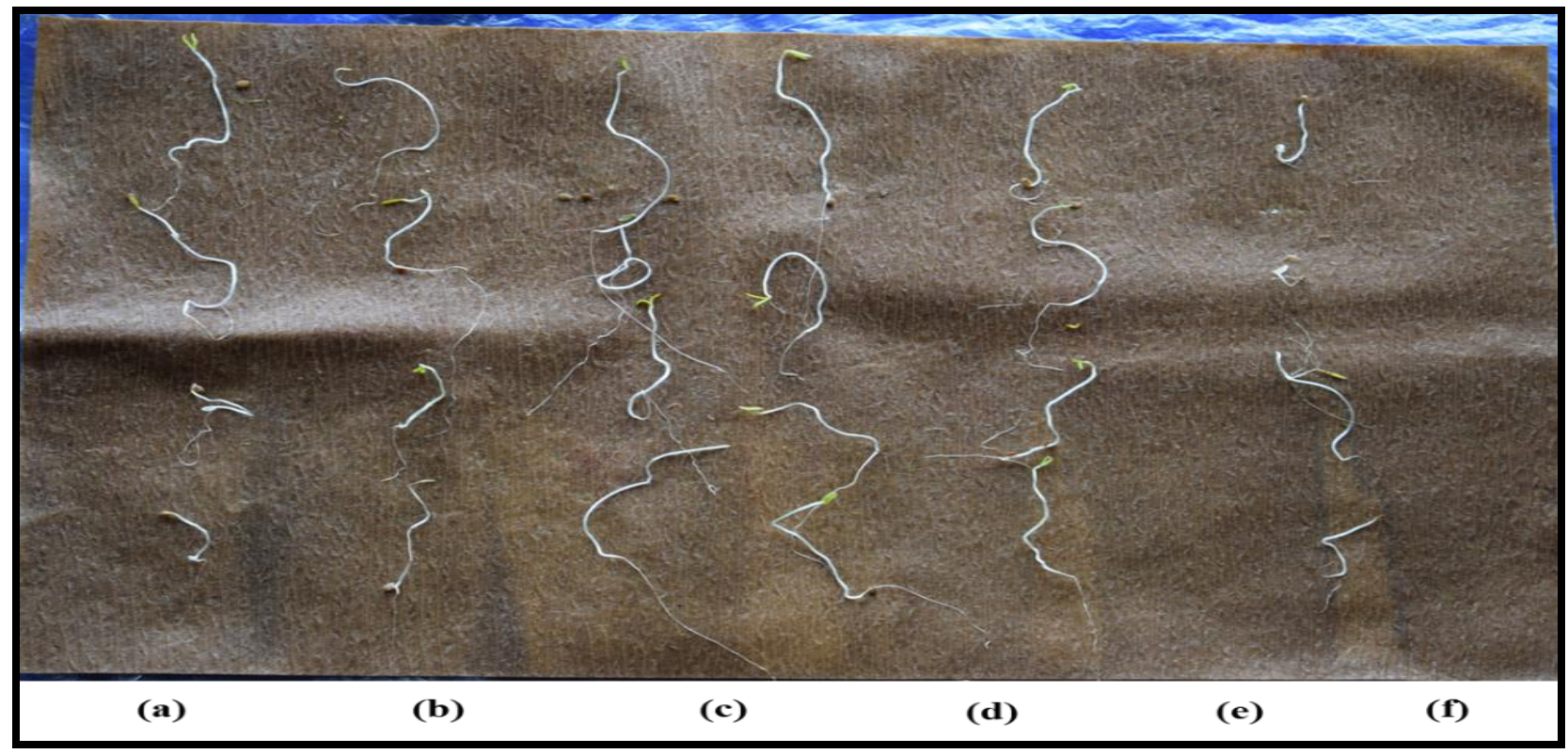

Plate.8 Tomato plant growth response by rhizobacterial isolates using pot culture technique under green house condition

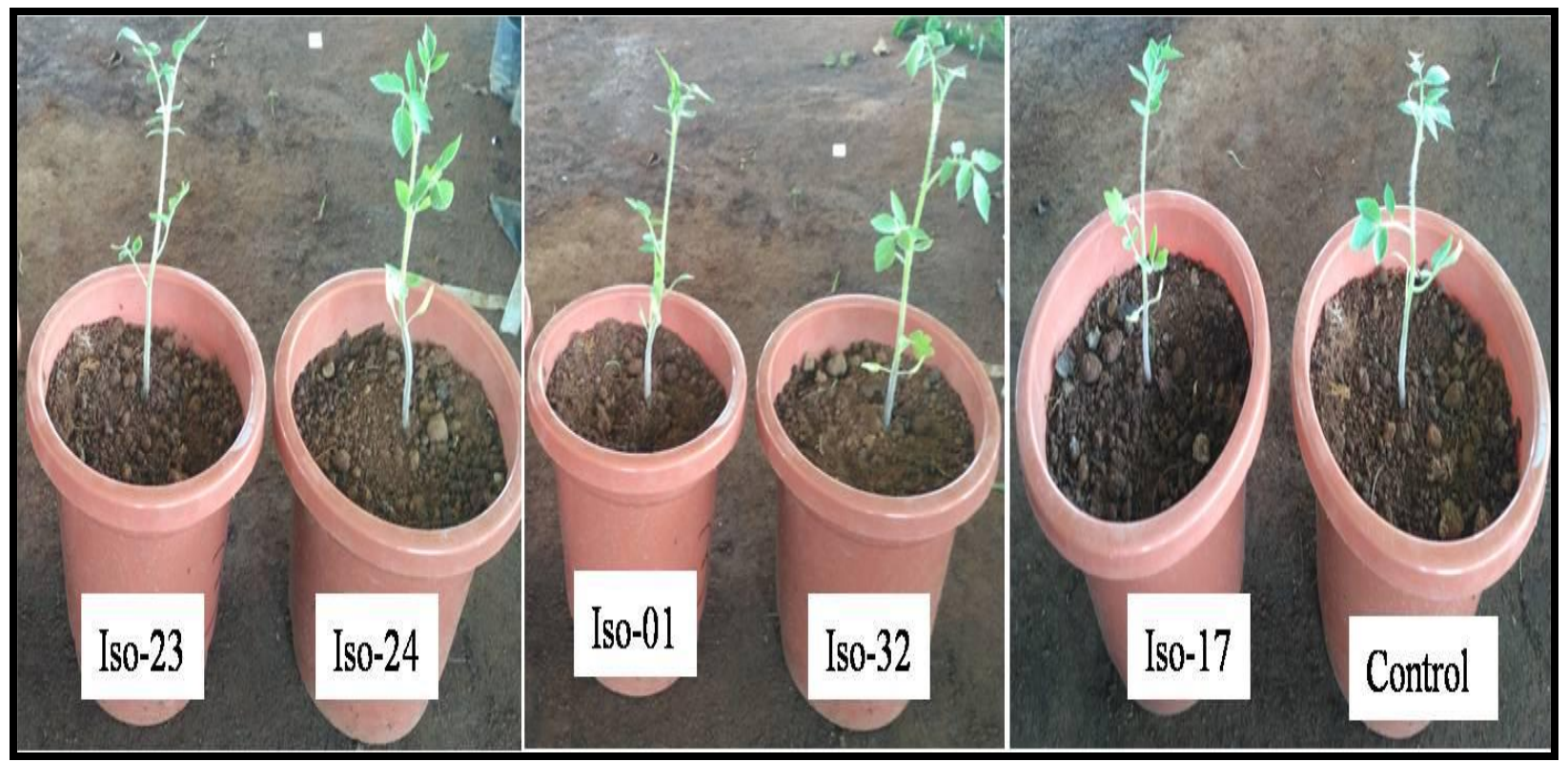

Significant variation in germination was recorded. It varied from $96.25 \%$ to $85 \%$, with highest germination of $96.25 \%$ in seeds treated with isolate-32 as compared to $85 \%$ germination in untreated seed control. Seed treatment with different rhizobacterial isolates, showed significant variation with respect to root length, shoot length and seedling vigour index. The maximum shoot length $(7.98 \mathrm{~cm})$ was recorded in isolate- 23 as against minimum shoot length $(3.90 \mathrm{~cm})$ in control. The maximum root length $(7.66 \mathrm{~cm})$ was recorded in isolate-23 as compared to root length of $(3.90 \mathrm{~cm})$ in control seedlings. 
The highest vigour index (1419.1) could be achieved by the seedlings treated with Isolate23 closely followed by vigour index (1387.3) in seedlings treated with Isolate-24 where as in control (680.1).

\section{Efficacy of rhizobacterial treatment by root dip method on plant growth parameters under greenhouse condition}

Results of pot experiment conducted in green house for in vivo evaluation of effect of root dip treatment of rhizobacterial isolates on the plant growth parameters such as shoot length, root length, and fresh and dry weight (Table 4).

The highest root length of $15.40 \mathrm{~cm}$ was observed in treatment with Isolate-24 followed by $15.33 \mathrm{~cm}$ in Isolate-32. The highest shoot length was recorded in the Isolate-32\&24 $(15.58 \mathrm{~cm})$ and followed by Isolate-17 $(15.40 \mathrm{~cm})$. The maximum fresh root weight was observed in the Isolate-32 $(0.96 \mathrm{~g})$, which was statistically at par with Isolate-24 (0.94 g). Similarly, maximum root dry weight was observed in the Isolate-17 $(0.53 \mathrm{~g})$ followed by Isolate-32 $(0.50 \mathrm{~g})$, significantly higher than control $(0.30 \mathrm{~g})$. Highest shoot fresh weight was recorded in the isolate- $24 \& 32$ treatment $(1.43 \mathrm{~g})$ followed by Isolate-17 (1.41 g), which were significantly higher as compared to the control $(0.56 \mathrm{~g})$. The maximum shoot dry weight was recorded in the Isolate- $32(0.98 \mathrm{~g})$ followed by Isolate-24 (0.86g). All the treatments were statistically at par with each other.

In conclusion, native microbes are best bets while bioprospecting agriculturally important microorganisms from any agro-ecological system. Vegetables being highly economically important crop receive more pesticides for management of several pest and diseases. However, as the fruits, the edible parts of the plants, come in direct contact with deadly pesticides, it is imperative to explore more native microbes which can counter pathogens more effectively. The present study concluded that native rhizobacterial strains isolated from the tomato crop can be successfully used for managing soil borne Sclerotium $s p$. affecting tomato crop besides enhancing the growth of the treated plants. Among five rhizobacterial isolates two isolates isolate-32 and isolate-24 identified as having highly potential antagonistic properties along with plant growth promotion ability, which would pave way for ecofriendly management of collar rot of tomato.

\section{References}

Aycock, R., (1966). Stem rot and other diseases caused by $S$. rolfsii. Tech. Bull. No.174. Agric. Expt. Station, North Carolina State University, Raleigh. 202 p.

Baki AA, and Anderson JD, (1972). Physiological and Biological deterioration of seeds. In: Seed Biology. Vol. 11, Academic Press, New York. 283-315 pp.

Banyal, D. K., Mankotia, V., and Sugha, S. K., (2008). Soil characteristics and their relation to the development of tomato collar rot caused by Sclerotium rolfsii. Indian Phytopathology. 61(1):103-107.

Begum, S. N., Chowdhury, B. C., and Ahamed, H. U., (1985). Screening of brinjal varieties for resistance to $S$. rolfsii. Abst. 1st National Conf. Plant Pathology, held at Bangladesh Agricultural Research Institute, Joydebpur, Gazipur. 12 p.

Bhattacharrya, S. K., Phadtare, S. G., and Sharma, V. C., (1977). Fungal diseases of potato. Recent technology in potato improvement and production. CPRI. Simpla. India. 209-237 p.

Buysens. S., and scheffer, RJ., (1992). 
Screening systems for bio-control and growth promotion. Bulletin Oilb/Srop., 15: $145-146$.

Dennis, C., and Webster J., (1971). Antagonist properties of species group of Trichoderma II. Production of volatile antibiotics. Trans British Mycology Socity, 57: 41 -48.

Frankenberger, W.T., and Arshad, M. (1995). Phytohormones in Soils: Microbial Production and Function. Marcel Dekker, New York, Pp 520

Islam T., (2009). Population dynamics of phomopsisvexans, sclerotium rolfsii, fusarium oxysporum f. splycopersici and trichodermain the soil of eggplant field. An M.S. thesis submitted to the Dept. of Plant Pathology, Bangladesh Agricultural University, Mymensingh. 48-57 pp.

Kloepper, J.W., Estrad, G. and Mclnroy, J.A.,(2007). Photoperiod regulates elicitation of growth promotion but not induced resistance by plant growthpromoting rhizobacteria. Canadian Journal of Microbiology 53: 159-167.

Kloepper, J.W., Leong, J., Terntze, M. and Schroth, M.N. (1980). Enhanced plant growth by siderophores produced by plant growth-promoting rhizobacteria. Nature 286: 885-886.

Lemessa, F., and Zeller W., (2007). Screening rhizobacteria for biological control of
Ralstonia solanacearum in Ethiopia, Biological Control, 42, 3, (336).

Panse, VG., and Sukhatme, PV., (1989). Statistical Methods for Agricultural Workers. 4th edn. ICAR. New Delhi.

Raaska, L., Viikari, L., and MattilaSandholm, T.,(1993). Detection of siderophores in growing cultures of Pseudomonas spp. Journal of Industrial Microbiology 11: 181-186.

Srinivasan K, Gilardi G and Garibaldi A, (2009). Bacterial antagonists from used rockwool soilless substrates suppress Fusarium wilt of tomato. Journal Plant Pathology, 91:147-54.

Talukder, M. J., (1974). Plant diseases in Bangladesh, Bangladesh J. Agril. Res. 1(1): 61-86.

Thiribhuvanamala, G., Rajeswari, E., and SabithaDoraiswamy(1999). Inoculum levels of Sclerotium rolfsii on the incidence of stem rot in tomato. Madras Agricultural Journal. 86: 334.

Vincent, JM., (1927). Distortion of fungal hyphae in the presence of certain inhibitors. Nature. 159: 850.

Winstead, NN and Kelman, A., (1952). Inoculation techniques for evaluating resistance to Pseudomonas solanacearum. Phytopathology, 42: 628-634.

\section{How to cite this article:}

Bhanothu Shiva, P. Srinivas and Deepa Khulbe. 2019. Efficacy of Rhizosphere Bacterial Antagonists and Plant Growth Promoting Rhizobacteria against Sclerotium rolfsii Affecting Tomato Plants. Int.J.Curr.Microbiol.App.Sci. 8(07): 2274-2285. doi: https://doi.org/10.20546/ijcmas.2019.807.278 